DOI:10.17951/h.2020.54.2.31-40

\begin{tabular}{lcc}
\hline \multicolumn{1}{c}{ A N N A L E S } \\
UNIVERSITATIS MARIAE CURIE-SKŁODOWSKA \\
LUBLIN - POLONIA \\
VOL. LIV, 2 & SECTIOH H \\
\hline
\end{tabular}

\title{
SYLWESTER KOZAK
}

sylwester_kozak@sggw.pl

Warsaw University of Life Sciences - SGGW. Institute of Economics and Finance

166 Nowoursynowska St., 02-787 Warsaw

ORCID ID: https://orcid.org/0000-0001-9485-6704

\section{Are Larger Banks More Efficient in the Central Eastern European Countries?}

Keywords: CEE countries; bank; efficiency; market share

JEL: G10; G15; G21

How to quote this paper: Kozak, S. (2020). Are Larger Banks More Efficient in the Central Eastern European Countries?. Annales Universitatis Mariae Curie-Skłodowska, sectio H - Oeconomia, Vol. 54, No. 2.

\footnotetext{
Abstract

Theoretical background: The relationship between the size of banks and their efficiency has become an important subject for academics and policy makers in the recent decades. However, the outcomes of these studies are relatively divergent concerning the direction of this dependence.

Purpose of the article: The goal of this study is to assess how the size of banks affects their efficiency in the CEE countries in the years 2005-2017. Additionally, the relationship between the market concentration and banks efficiency is checked.

Research methods: The research covers 108 banks operating in eleven CEE countries. The efficiency scores are achieved through the SFA method and regressed with the individual bank characteristics and macroeconomic and sectoral variables.

Main findings: The results show that growing bank's size and market share positively affect its efficiency. Additionally, higher concentration of the banking market has a similar effect. Higher inflation and GDP per capita decrease bank profit efficiency which can indicate that banks achieve the highest efficiency gains in less prosperous countries, however, in the low inflation environment. Additionally, banks' efficiency is boosted with the growing development of the banking sector and increasing lending to the economy. Fast-growing banks tend to be more efficient, probably due to the positive effect of the financial leverage on profits.
} 


\section{Introduction}

The efficiency of the banking sector has become an important subject for academics and policy makers in the recent decades (Berger, Hasan, \& Zhou, 2009; Duygun, Sena, \& Shaban, 2013; Mesa, Sánchez, \& Sobrino, 2014; Niţoi \& Spulbar, 2015; Silva, Guerra, Tabak, \& de Castro Miranda, 2016; Peng, Jeng, Wang, \& Chen, 2017; Avramidis, Cabolis, \& Serfes, 2018). Among them, studies analyze the relationship between the size of banks and their efficiency. However, the outcomes of these studies are relatively divergent. Some of them indicate that the size of banks positively impacts their performance (Berger, Demsetz, \& Strahan, 1999; Haynes \& Thompson, 1999; Bikker \& Haaf, 2002; Amel, Barnes, Panetta, \& Salleo, 2004), however, others notice an opposite direction of this dependence (Rhoades, 1999; Mamatzakis, Matousek, \& Vu, 2016) or do not find any significant relationship (Avkiran, 1999; Casu \& Girardore, 2006). Similar discrepancies are recognized in the assessment of the possible impact of the concentration of the banking structure. The difference in the obtained conclusions may come from the fact that these studies were conducted in various macroeconomic conditions and timeframes, as well as sets of examined banks operating in different geographical regions.

The goal of this study is to determine how the size of banks affects their efficiency in the Central Eastern European (CEE) countries in the years 2005-2017. Additionally, the relationship between the market concentration and banks efficiency is checked. The timeframe of the research was chosen in such a way as to cover periods of economic growth, as well as crises or slowdowns. During the analysed period, CEE banks' activity was exposed to the effects of the global financial crisis of 2007-2009 and the crisis of public finance in some euro area countries in 2011-2013. The research refers to 108 banks which operate in eleven CEE countries. In the study the hypothesis was made that banks can improve their efficiency by increasing the value of their assets.

The study fills the existing gap in literature on the relationship between the size of the bank and its efficiency in the banking sector in the CEE countries in the preand post-global financial crisis period. It shades a new perspective on the banking market concentration versus banks' efficiency relationship, as well. Additionally, it takes into consideration the impact of some macroeconomic variables on bank's efficiency as: GDP per capita, inflation rate, level of development of the banking sector, as well as the individual bank's capital ratio.

The rest of the paper consists of three sections and conclusions. The first one presents conclusions from the literature review, the second - data and methods used in the research, and the third discusses the results of the research. Finally, the entire study is summarized. 


\section{Banks' size and efficiency - literature review}

The literature does not present a uniform answer to the question about the impact of the size of the bank on its performance. The conclusions of the studies presented in the literature explain this relationship using two theories: the market power (MP) theory and the efficient structure (ES) theory. The first one states that bank's performance significantly depends on the structure of the market (the structure-conduct-performance paradigm, SCP). In the more concentrated sector, larger banks can gain a monopolistic premium, which enables them to set more favorable for them prices and improve their efficiency and profitability. The ES theory states that due to the competitive advantage, more efficient enterprises are able to grow at the expense of less viable competitors and with the economy of scale become even larger and more efficient (Demsetz, 1973). In the banking sector, efficient banks can lower prices of their products, become more competitive and gain new customers.

The relationship between the size of enterprises and their performance was developed by Bain (1951). He stated that in the market with smaller number of enterprises, the market participants increase prices and achieve higher profits. Such conduct has been also noticed in the research conducted on banks over the last few decades. Gilbert (1984) states that in the 1960s, as a result of changes in the legal regulations concerning the effects of bank mergers, large U.S. banks were able to offer lower rates on deposits and higher rates on loans and thus raise their profits and efficiency.

Hay and Liu (1997) confirm the existence of the positive relationship between bank's market share and efficiency. Large banks due to the solid cost policy improve efficiency of their operations and raise profitability. In consequence, they become larger and increase market share. Similarly Boot and Schmeits (2005) state that larger banks may withstand harsh competition and increase further their size and market share. Especially during an economic downturn, smaller units could not afford to develop new products and expose themselves to the risk of losing customers. Larger banks are able to provide competitive products, operate with larger network of offices and maintain customer loyalty.

Results of the research conducted by Evanoff and Fortier (1988) on the U.S. banking sector in the 1970s and 1980s indicate that more efficient banks acquire less competitive entities, inter alia, based on their size and cost reduction ability. In the recent decade, using the ES theory, Homma, Tsutsui, and Uchida (2014) explain the behaviour of Japanese banks which operate in the period 1974-2005. They state that large banks operate more efficiently and gain larger market share due to acquiring less efficient and weaker performing competitors.

The research on the relationship between the bank's size and its performance in the CEE countries is rather limited. Among them Andries and Ursu (2016), based on the research on banks operating in seven CEE countries over the period of 2004-2008, find that banks' efficiency characterises in an upward trend and is positively affected by the level of banking sector concentration and the size of banks. Efthyvoulou and 
Yildirim (2014), based on the performance of banks in seventeen CEE countries over the period 2002-2010, assess their market power and efficiency. They notice a significant inconsistency in these variables in the analysed countries and diversified responses of banks to the effects of the financial crisis, among others, due to the ownership structure. Most of other papers concentrate rather on assessing banks' efficiency (Anayiotos, Toroyan, \& Vamvakidis, 2010; Poghosyan \& Poghosyan, 2010; Tuskan \& Stojanovic, 2016).

\section{Data and research methods}

The parametric method - stochastic frontier approach (SFA) - was used for estimating the profit efficiency scores for each bank in the sample. The nonparametric DEA method is an alternative way of measuring bank's efficiency. An important advantage of the DEA method is the ability to determine efficiency for a small number of entities. However, its disadvantage is that outliers or data errors are not filtered out and significantly distort efficiency scores of the analysed entities. The misspecification problem is eliminated in the statistical SFA method. Given the fact that the research sample consists of 108 banks, it is justified to use the SFA method. The one-step approach model of Battese and Coelli (1995) was applied. The profit function is the multi-product trans-log specification:

$\ln \frac{\text { Prof }_{i t}}{W 3_{i t}}=b_{0}+b_{1} \ln \left(\frac{W 1_{i t}}{W 3_{i t}}\right)+b_{2} \ln \left(\frac{W 2_{i t}}{W 3_{i t}}\right)+b_{3} \ln \left(Q 1_{i t}\right)+b_{4} \ln \left(Q 2_{i t}\right)+b_{5} \frac{1}{2}\left(\ln \left(Q 1_{i t}\right)\right)^{2}+$ $b_{6} \frac{1}{2}\left(\ln \left(Q 2_{i t}\right)\right)^{2}+b_{7} \ln \left(Q 1_{i t}\right) \ln \left(Q 2_{i t}\right)+b_{8} \frac{1}{2}\left(\ln \left(\frac{W 1_{i t}}{W 3_{i t}}\right)\right)^{2}+b_{9} \frac{1}{2}\left(\ln \left(\frac{W 2_{i t}}{W 3_{i t}}\right)\right)^{2}+$ $b_{10} \ln \left(\frac{W 1_{i t}}{W 3_{i t}}\right) \ln \left(\frac{W 2_{i t}}{W 3_{i t}}\right)+b_{11} \ln \left(\frac{W 1_{i t}}{W 3_{i t}}\right) \ln \left(Q 1_{i t}\right)+b_{12} \ln \left(\frac{W 1_{i t}}{W 3_{i t}}\right) \ln \left(Q 2_{i t}\right)+$ $b_{13} \ln \left(\frac{W 2_{i t}}{W 3_{i t}}\right) \ln \left(Q 1_{i t}\right)+b_{14} \ln \left(\frac{W 2_{i t}}{W 3_{i t}}\right) \ln \left(Q 2_{i t}\right)+b_{15} \frac{1}{2} T_{t}^{2}+b_{16} \ln \left(\frac{W 1_{i t}}{W 3_{i t}}\right) T_{t}+b_{17} \ln \left(\frac{W 2_{i t}}{W 3_{i t}}\right) T_{t}+$ $b_{18} \ln \left(Q 1_{i t}\right) T_{t}+b_{19} \ln \left(Q 2_{i t}\right) T_{t}+b_{20} \ln \left(E q_{-} T A_{i t}\right)+b_{21} \ln \left(\frac{W 1_{i t}}{W 3_{i t}}\right) \ln \left(E q_{-} T A_{i t}\right)+$ $b_{22} \ln \left(\frac{W 2_{i t}}{W 3_{i t}}\right) \ln \left(E q_{-} T A_{i t}\right)+b_{23} \ln \left(Q 1_{i t}\right) \ln \left(E q_{-} T A_{i t}\right)+b_{24} \ln \left(Q 2_{i t}\right) \ln \left(E q_{-} T A_{i t}\right)+$ $b_{25} \ln \left(E q_{-} T A_{i t}\right) T_{t}+v_{i t}+u_{i t}$

where: the dependent variable Prof is measured with a bank Operating Income. The bank is treated as a financial intermediary generating loans and other earning assets from deposits and other financial liabilities with the use of labor and fixed assets. In the model, two outputs are considered: Loans (Q1) and Other Financial Assets (estimated as Financial Assets - Net Total Loans) (Q2). The inputs comprise: (1) Fixed Assets (X1), (2) Labor (X2), and (3) Total Financial Liabilities (X3) (Andries \& Ursu, 2016; Barth, Lin, \& Ma, 2013; Halkos, Tzeremes, \& Nickolaos, 2013). 
The prices of inputs are calculated according to the following formulas:

- Cost of Physical Capital (W1) - the sum of Equipment and Depreciation divided by Fixed Assets,

- Cost of Labor (W2) - Compensation and Benefits Expense over Total Assets,

- Cost of Funds (W3) - Interest Expense over Total Financial Liabilities.

Following the study of Berger and Mester (1997) and Andries and Ursu (2016), the ratio of Equity to Total Assets (Eq_TA) is included as an input to control for differences across banks' risk preferences. To introduce linear homogeneity restrictions, the dependent variable and all three input prices are normalized by the Cost of Funds - W3. Finally, the time dummy (T) is employed to allow for technological and other time-specific changes (Lensink, Meesters, \& Naaborg, 2008; Lozano-Vivas \& Pasiouras, 2010; Andries \& Ursu, 2016). Based on estimation of equation (1), the values of inefficiency effects $u_{i t}$ are obtained and next efficiency scores $\eta_{i t}$ are calculated using the formula $\exp \left\{-u_{i t}\right\}$.

In order to investigate the relationship between bank profit efficiency across CEE countries and bank's size, efficiency scores $\eta_{i t}$ are regressed on the bank's size and potential explanatory variables describing macroeconomic situation, each country banking sector, and bank-specific situation according to the following specification:

$$
\begin{aligned}
& \eta_{\mathrm{it}}=\delta_{0}+\delta_{1} \text { bank_size }_{i t}+\delta_{2} \text { gdp_cap }_{\mathrm{jt}-1}+\delta_{3} \mathrm{infl}_{\mathrm{jt}-1}+\delta_{4} \text { loan_gdp }_{\mathrm{jt}}+\delta_{5} \mathrm{CR}_{\mathrm{jt}}+ \\
& \delta_{6} T C R+\varepsilon_{\mathrm{it}}
\end{aligned}
$$

The positive coefficient would mean that the determinant increases bank profit efficiency. In the equation (2), GDP per capita (gdp_cap) and Inflation (infl) measure income level and change in annual average consumer price level. Ratio of Banking Loans to GDP (loan_gdp) represents the level of development of financial intermediation in a particular country. Market concentration (CR) is measured with two indicators: the Market Share of the 5 Largest Banks in a country (CR5) and the Herfindahl-Hirschman Index (HHI). The size of the bank is represented by a natural logarithm of bank total assets (bank_size) and an individual bank Market Share (M_Sh) estimated as a ratio of a bank's total assets to total bank assets in a country. In order to control for characteristics of a bank, the Total Capital Ratio (TCR) is employed.

Data on individual banks are obtained from the SNL database. Data on the rate of inflation, GDP per capita and loans to GDP come from Eurostat, while data on the market concentration come from the ECB Statistical Data Warehouse. All data are of annual frequency and cover the period between 2005 and 2017. The research concerns eleven CEE countries: Bulgaria (9 banks), the Czech Republic (11), Estonia (6), Croatia (16), Hungary (9), Lithuania (7), Latvia (7), Poland (21), Romania (9), Slovenia (5), and Slovakia (8). 


\section{Results and discussion}

In the first stage of the analysis, banks' profit inefficiency scores $u_{i t}$ and next efficiency scores $\eta_{i t}$ are calculated with the use of the trans-log equation (1). Table 1 presents the values of average efficiency scores for the individual countries and for individual years.

Table 1. Average profit efficiency scores

\begin{tabular}{|l|c|c|c|}
\hline \multicolumn{1}{|c|}{ Country } & PE* & Year & PE** \\
\hline Bulgaria & $85.4 \%$ & 2005 & $87.7 \%$ \\
\hline Czech Republic & $85.2 \%$ & 2006 & $86.2 \%$ \\
\hline Estonia & $83.3 \%$ & 2007 & $83.8 \%$ \\
\hline Croatia & $83.8 \%$ & 2008 & $81.6 \%$ \\
\hline Hungary & $83.1 \%$ & 2009 & $82.5 \%$ \\
\hline Lithuania & $83.2 \%$ & 2010 & $82.9 \%$ \\
\hline Latvia & $86.1 \%$ & 2011 & $86.1 \%$ \\
\hline Poland & $82.9 \%$ & 2012 & $83.3 \%$ \\
\hline Romania & $84.9 \%$ & 2013 & $79.8 \%$ \\
\hline Slovenia & $76.8 \%$ & 2014 & $84.1 \%$ \\
\hline Slovakia & $87.9 \%$ & 2015 & $83.8 \%$ \\
\hline & & 2016 & $84.1 \%$ \\
\hline \multicolumn{2}{|r|}{} & 2017 & $83.6 \%$ \\
\hline
\end{tabular}

Note: PE - profit efficiency score, * average for the entire period, ** average over all countries.

Source: Author's own study based on the SNL data.

The results indicate that efficiency of banks in the CEE countries is rather high, however, slightly diverse. The distribution of the efficiency scores is rather concentrated around the average of $84 \%$ (the value of kurtosis 2.75 ). The two extreme values of efficiency refer to Slovenia, with the least efficient banking sector of $76.8 \%$, and Slovakia, with the most efficient banking sector of $87.9 \%$. Analyzing CEE banks' performance over the entire period it can be noticed that they operate with a variable efficiency. Efficiency scores for individual years indicate that banks' efficiency drops in the periods of macroeconomic slowdown caused by the financial crisis of 2007-2009 and by the crisis of public finances in the euro area of 2012-2013. After these periods, banks significantly restored their efficiency.

In the second stage of the research, the impact of bank's size and market share on the efficiency scores $\eta_{i t}$ was checked. The controlling by macroeconomic, sectoral and bank individual variables were applied. The results confirm the assumption of the significant impact of the bank's size on its efficiency (Table 2). Additionally, the results confirm the increase in the market concentration, measured both with CR5 and HHI, positively affects individual bank's efficiency (Model 5 and 6). As the coefficients in Models 1 and 2 indicate, bank's efficiency improves with the increase of the market share and total assets. The result proved the research hypothesis which 
states that banks can raise their efficiency by increasing their assets and the market share. For a robustness check efficiency was regressed with variables representing bank's capital capacity (Models 3 and 4).

Table 2. Relationship between profit efficiency scores and macroeconomic and individual bank variables

\begin{tabular}{|c|c|c|c|c|c|c|}
\hline Variable & Model 1 & Model 2 & Model 3 & Model 4 & Model 5 & Model 6 \\
\hline 1.GDPpc & $\begin{array}{l}-0.040 \\
(0.034)\end{array}$ & $\begin{array}{c}-0.031 \\
(0.033)\end{array}$ & $\begin{array}{l}-0.042^{*} \\
(0.023)\end{array}$ & $\begin{array}{l}-0.039^{*} \\
(0.021)\end{array}$ & $\begin{array}{c}-0.113^{* * *} \\
(0.036)\end{array}$ & $\begin{array}{c}-0.103^{\text {**** }} \\
(0.035)\end{array}$ \\
\hline 1.Inflation & $\begin{array}{l}-0.006^{*} \\
(0.003)\end{array}$ & $\begin{array}{l}-0.006 \\
(0.000)\end{array}$ & $\begin{array}{c}-0.006^{* *} \\
(0.003)\end{array}$ & $\begin{array}{c}-0.006^{* * *} \\
(0.003)\end{array}$ & $\begin{array}{c}-0.007^{* * *} \\
(0.003)\end{array}$ & $\begin{array}{c}-0.007^{* * *} \\
(0.003)\end{array}$ \\
\hline Loan_GDP & $\begin{array}{c}0.001^{*} \\
(0.000)\end{array}$ & $\begin{array}{c}0.001^{*} \\
(0.000) \\
\end{array}$ & $\begin{array}{l}0.001^{* *} \\
(0.000)\end{array}$ & $\begin{array}{l}0.001^{* *} \\
(0.000)\end{array}$ & $\begin{array}{c}0.001^{* * * *} \\
(0.000)\end{array}$ & $\begin{array}{l}0.001^{* * *} \\
(0.000)\end{array}$ \\
\hline CR5 & - & - & - & - & $\begin{array}{c}0.004^{* * *} \\
(0.001)\end{array}$ & - \\
\hline HHI & - & - & - & - & - & $\begin{array}{c}0.941^{* * *} \\
(0.243)\end{array}$ \\
\hline M_Sh & $\begin{array}{l}0.211^{\text {**** }} \\
(0.091)\end{array}$ & - & $\begin{array}{c}0.419^{* * *} \\
(0.142)\end{array}$ & - & - & - \\
\hline Bank_size & - & $\begin{array}{l}0.058^{* *} \\
(0.027)\end{array}$ & - & $\begin{array}{l}0.352^{* *} \\
(0.171)\end{array}$ & $\begin{array}{c}0.058^{* * * *} \\
(0.012)\end{array}$ & $\begin{array}{l}0.057^{* *} \\
(0.027)\end{array}$ \\
\hline TCR & - & - & $\begin{array}{c}-0.005^{* *} \\
(0.002)\end{array}$ & $\begin{array}{c}-0.005^{* *} \\
(0.002)\end{array}$ & $\begin{array}{c}-0.005^{\text {**** }} \\
(0.002)\end{array}$ & $\begin{array}{c}-0.005^{\text {**** }} \\
(0.002)\end{array}$ \\
\hline Constant & $\begin{array}{c}0.146 \\
(0.296)\end{array}$ & $\begin{array}{c}0.141 \\
(0.294)\end{array}$ & $\begin{array}{c}0.112 \\
(0.211)\end{array}$ & $\begin{array}{c}0.357 \\
(0.211)\end{array}$ & $\begin{array}{c}-0.125 \\
(0.305)\end{array}$ & $\begin{array}{c}-0.235 \\
(0.303)\end{array}$ \\
\hline $\mathrm{N}$ & 714 & 714 & 714 & 714 & 714 & 714 \\
\hline R2 & 0.046 & 0.043 & 0.062 & 0.057 & 0.119 & 0.112 \\
\hline F-stat & 3.83 & 3.61 & 5.43 & 4.87 & 5.36 & 4.92 \\
\hline
\end{tabular}

Note: 1.GDPpc, 1.Inflation - GDP per capita, inflation rate lagged one year; standard errors in brackets, ${ }^{* * *},{ }^{* *},{ }^{*}$ represent $1 \%, 5 \%$ and $10 \%$ significance level, respectively.

Source: Author's own study based on the SNL data.

The outcome of these regressions is consistent with the ES theory, which states that more efficient banks grow by increasing their market share at the expense of the less competitive institutions. ${ }^{1}$ Referring to the macroeconomic variables, the results of the research imply that higher inflation and GDP per capita decrease bank profit efficiency which can indicate that banks achieve the highest efficiency gains in less prosperous countries, however, in the low inflation environment. Additionally, banks' efficiency is boosted with the growing development of the banking sector and increasing lending to the economy. Bank efficiency is impacted by bank's individual characteristics. Negative coefficient at TCR ratio shows that fast-growing banks with lower capital equipment tend to be more efficient, probably due to the positive effect of the financial leverage on profits.

1 The National Bank of Poland reported in 2018 that for some recent period in Poland large banks have become more efficient and earn majority of profits of the banking sector, see: Box 2.5 Concentration of earnings of domestic commercial banks (Raport o stabilności systemu finansowego, 2018, pp. 57-58). 


\section{Conclusions}

This paper presents the study on the relatively rarely described problem of the impact of bank's size on its profit efficiency in CEE countries in the years 2005-2017. The results show that in the analysed period, banks were characterized by relatively high profit efficiency, although diversified across the countries. The average efficiency throughout the region significantly decreased during the financial crisis of 2007-2009, as well as during the economic slowdown following the public finance crisis in the euro area.

The analysis of the relationship between the level of efficiency and individual and macroeconomic factors show that banks with a higher asset value and having a larger market share achieve higher efficiency. Additionally, higher concentration of the banking market has a similar positive effect on the banks' efficiency.

Referring to the macroeconomic variables, the results imply that higher inflation and GDP per capita decrease bank profit efficiency. Such relationship indicates that banks achieve the highest efficiency gains in less developed countries, however, in the low inflation environment. Additionally, banks' efficiency is boosted with the growing development of the banking sector and increasing lending to the economy. Bank efficiency is impacted by banks' individual characteristics, as well. Negative coefficient at TCR ratio shows that fast-growing banks tend to be more efficient, probably due to the positive effect of the financial leverage on profits.

\section{References}

Amel, D., Barnes, C., Panetta, F., \& Salleo, C. (2004). Consolidation and efficiency in the financial sector: A review of the international evidence. Journal of Banking \& Finance, 28. doi:10.1016/j.jbankfin.2003.10.013

Anayiotos, G., Toroyan, H., \& Vamvakidis, A. (2010). The efficiency of emerging Europe's banking sector before and after the recent economic crisis. Financial Theory and Practice, 34(3).

Andries, A., \& Ursu, S. (2016). Financial crisis and bank efficiency: An empirical study of European banks. Economic Research - Ekonomska Istraživanija, 29(1). doi:10.1080/1331677X.2016.1175725

Avkiran, N. (1999). The evidence on efficiency gains: The role of mergers and the benefits to the public. Journal of Banking \& Finance, 23(7). doi:10.1016/S0378-4266(98)00129-0

Avramidis, P., Cabolis, Ch., \& Serfes, K. (2018). Bank size and market value: The role of direct monitoring and delegation costs. Journal of Banking and Finance, 93. doi:10.1016/j.jbankfin.2018.05.016

Bain, J. (1951). Relation of profit rates to industry concentration. Quarterly Journal of Economics, 55. doi:10.2307/1882217

Barth, J., Lin, Ch., \& Ma, Y. (2013). Do bank regulation, supervision and monitoring enhance or impede bank efficiency? Journal of Banking \& Finance, 37. doi:10.1016/j.jbankfin.2013.04.030

Battese, G., \& Coelli, T. (1995). A model for technical inefficiency effects in a stochastic frontier production function for panel data. Empirical Economics, 20.

Berger, A., Demsetz, R., \& Strahan, P. (1999). The consolidation of the financial services industry: Causes, consequences, and implications for the future. Journal of Banking \& Finance, 23.

doi:10.1016/S0378-4266(98)00125-3 
Berger, A., Hasan, I., \& Zhou, M. (2009). Bank ownership and efficiency in China: What will happen in the world's largest nation? Journal of Banking \& Finance, 33. doi:10.1016/j.jbankfin.2007.05.016

Berger, A., \& Mester, L. (1997). Inside the black box: What explains differences in the efficiencies of financial institutions? Journal of Banking \& Finance, 21. doi:10.1016/S0378-4266(97)00010-1

Bikker, J., \& Haaf, K. (2002). Competition, concentration and their relationship: An empirical analysis of the banking industry. Journal of Banking \& Finance, 26.

Boot, A., \& Schmeits, A. (2005). The competitive challenge in banking. Amsterdam Center for Law \& Economics Working Paper, 2005-08.

Casu, G., \& Girardore, C. (2006). Bank competition, concentration and efficiency in the single European market. The Manchester School, 74(4). doi:10.1111/j.1467-9957.2006.00503.x

Demsetz, H. (1973). Industry structure, market rivalry, and public policy. Journal of Law and Economics, 16. doi:10.1086/466752

Duygun, M., Sena, V., \& Shaban, M. (2013). Schumpeterian competition and efficiency among commercial banks. Journal of Banking \& Finance, 37. doi:10.1016/j.jbankfin.2013.07.003.x

Efthyvoulou, G., \& Yildirim, C. (2014). Market power in CEE banking sectors and the impact of the global financial crisis. Journal of Banking \& Finance, 40. doi:10.1016/j.jbankfin.2013.11.010

Evanoff, D., \& Fortier, D. (1988). Reevaluation of the structure-conduct-performance paradigm in banking. Journal of Financial Services Research, 1(3).

Gilbert, R. (1984). Bank market structure and competition. Journal of Money, Credit, and Banking, 16. doi:10.2307/1992096p

Halkos, G., Tzeremes, E., \& Nickolaos, G. (2013). Estimating the degree of operating efficiency gains from a potential bank merger and acquisition: A DEA bootstrapped approach. Journal of Banking \& Finance, 37. doi:10.1016/j.jbankfin.2012.12.009

Hay, D., \& Liu, G. (1997). The efficiency of firms: What difference does competition make? The Economic Journal, 107(442). doi:10.1111/j.1468-0297.1997.tb00029.x

Haynes, M., \& Thompson, S. (1999). The productivity effects of bank mergers: Evidence from the UK building societies. Journal of Banking \& Finance, 23. doi:10.1016/S0378-4266(98)00117-4

Homma, T., Tsutsui, Y., \& Uchida, H. (2014). Firm growth and efficiency in the banking industry: A new test of the efficient structure hypothesis. Journal of Banking \& Finance, 40. doi:10.1016/j.jbankfin.2013.11.031

Lensink, R., Meesters, A., \& Naaborg, I. (2008). Bank efficiency and foreign ownership: Do good institutions matter? Journal of Banking \& Finance, 32. doi:10.1016/j.jbankfin.2007.06.001

Lozano-Vivas, A., \& Pasiouras, F. (2010). The impact of non-traditional activities on the estimation of bank efficiency: International evidence. Journal of Banking \& Finance, 34. doi:10.1016/j.jbankfin.2010.01.006

Mamatzakis, E., Matousek, R., \& Vu, A. (2016). What is the impact of bankrupt and restructured loans on Japanese bank efficiency? Journal of Banking \& Finance, 72. doi:10.1016/j.jbankfin.2015.04.010

Mesa, R., Sánchez, H., \& Sobrino, J. (2014). Main determinants of efficiency and implications on banking concentration in the European Union. Spanish Accounting Review, 17(1). doi:10.1016/j.rcsar.2013.08.006

Niţoi, M., \& Spulbar, C. (2015). An examination of banks' cost efficiency in Central and Eastern Europe. Procedia Economics and Finance, 22. doi:10.1016/S2212-5671(15)00256-7

Peng, P., Jeng, V., Wang, J., \& Chen, Y. (2017). The impact of bancassurance on efficiency and profitability of banks: Evidence from the banking industry in Taiwan. Journal of Banking \& Finance, 80. doi:10.1016/j.jbankfin.2017.03.013

Poghosyan, T., \& Poghosyan, A. (2010). Foreign bank entry, bank efficiency and market power in Central and Eastern European Countries. Economics of Transition, 18(3). doi:10.1111/j.1468-0351.2009.00378.x

Raport o stabilności systemu finansowego. (2018, grudzień). Warszawa: Departament Stabilności Finansowej, NBP. 
Pobrane z czasopisma Annales H - Oeconomia http://oeconomia.annales.umcs.pl Data: 26/04/2023 14:28:26

Rhoades, S. (1999). Efficiency effects of horizontal (in-market) bank mergers. Journal of Banking \& Finance, 17(2-3). doi:10.1016/0378-4266(93)90041-B

Silva, T., Guerra, S., Tabak, B., \& de Castro Miranda, R. (2016). Financial networks, bank efficiency and risk-taking. Journal of Financial Stability, 25(C).

Tuskan, B., \& Stojanovic, A. (2016). Measurement of cost efficiency in the European banking industry. Croatian Operational Research Review, 47. doi:10.17535/crorr.2016.0004 